\title{
OER and MOOC: The Need for Openness
}

\author{
Ismar Frango Silveira \\ Mackenzie Presbyterian University, São Paulo, SP, Brazil
}

\author{
ismar.silveira@mackenzie.br
}

\begin{abstract}
The Open Software movement serves as a landmark and a starting point for many "opensomething" initiatives, such as Open Educational Resources (OER) and Massive Online Open Courses (MOOC). However, under a pragmatic point-of-view, many of its basic principles are not considered specially when dealing with the above mentioned initiatives: common, industrystandard OER and MOOC lack a considerable set of really open features in a way that deviate the sense of the "O" letter - for Open - in its acronyms. Considering this, the present paper presents a systematization of these concepts around the general principle of openness. There will be discussed some strengths, challenges, and drawbacks in adopting openness as the key for OER and MOOC for Education in $21^{\text {st }}$ Century.
\end{abstract}

Keywords: Open Educational Resources, Massive Online Open Courses, 5R Principles, Open Licenses, Open Standards.

\section{Introduction}

The relatively recent advent of MOOCs (Massive Open Online Courses) brought to light some (inflamed) discussions regarding the potential and threats this model could bring to traditional teaching systems, both face-to-face and online. Such discussion led to another recent movement, about the open utilization of digital resources in educational contexts, named OER (Open Educational Resources). OER have their classic definition given by Atkins, Brown, and Hammond (2007) as educational materials available in public domain, published under an open license to access, use, remix, reuse and redistribute - with few or no limitations. Initially, the potential behind OER was to promote a truly individualized learning, which could be enhanced with social networks and therefore collaborative learning - OER could stand as the bricks that would be used to build a larger, rough granular educational resource, like a MOOC. However, time has shown that such potentialities did not convert to real scenarios.

The initial movement to establish the basis for OER is consistent with the general principles of openness. This is verifiable both from the point of view of technical opening (in consonance to Free Software and Hardware initiatives, for example), as well as the open access point of view.

Material published as part of this publication, either on-line or in print, is copyrighted by the Informing Science Institute. Permission to make digital or paper copy of part or all of these works for personal or classroom use is granted without fee provided that the copies are not made or distributed for profit or commercial advantage AND that copies 1) bear this notice in full and 2) give the full citation on the first page. It is permissible to abstract these works so long as credit is given. To copy in all other cases or to republish or to post on a server or to redistribute to lists requires specific permission and payment of a fee. Contact Publisher@,InformingScience.org to request redistribution permission.
This specific facet is shared with Open Education initiatives, widely made visible with the rise of MOOCs. Shuwer, van Genuchten, and Hatton (2015) bring a brief, but comprehensive, discussion about the so-called "open movements" which are the foundations for OER and MOOCs, considering different levels of opening for each one. 
It is known that current MOOCs seriously lack other aspects of openness, being focused just on open access - and they are gradually losing this feature, too, as shown in Yuan and Powell (2013). Besides, they lack consistent, open-access bibliographic materials, which bring a range of research challenges involving Open Educational Resources, as indicated by Rodés, Mustaro, Silveira, Omar, and Ochôa (2014). Regarding the current model of xMOOCs (or extended MOOCs) as opposed to the initial model cMOOCs (or connectionist MOOCs), a broader discussion is necessary about the impact of collaborative processes in education.

With the advent of MOOCs, promises of equal access to quality education comes up, and behind this proposal, networks of students, at least in theory, could replace the traditional tutors of current models of Distance Learning through the effective application of peer tutoring techniques. There are supporters and detractors of this approach - Russell and Klemer (2013) and Vardi (2012) bring good arguments about it - but the most commonly used argument is that MOOCs should not be seen as a way to eliminate teachers. Reality has shown that tutors have been already clearly eliminated, and that its true potential lies in the opportunity to support teachers, making them more available to talk with students in the time they were supposed to be lecturing.

Considering the Open Education a challenge to be faced by the academic community in general, some questions arise about how to achieve the benefits theoretically publicized by the Open Education, keeping the basic principles of openness. More specifically, it could be asked how to develop and maintain educational resources that are "really" open, which could potentially be supporters of courses - and also "really" open.

Regarding all this new scenario of research and development that could be unveiled by the openness perspective, this paper brings forth this discussion by giving a focus to technical and didactic perspectives with regard to the generation and maintenance of fully open courses and resources.

This work follows a survey-driven methodological approach, providing a comprehensive literature review and some systematizations in order to address the research question proposed. Some theoretical aspects of openness and OERs will be discussed in the next section, and these principles are used as a basis to systematize some challenges for MOOCs to adopt them, presented in the third section. At the end, a set of immediate effects of applying openness to MOOCs, as well as a wide range of potentialities that are possible to be developed under this scenario are presented, followed by conclusions and some directions for further work.

\section{The (Not So) Open Educational Resources}

Reuse always has been a key feature of the (already) old Learning Objects. Pioneers in this area, like Reigeluth and Nelson (1997) and Wiley (2000), constructed the theory among the "notion of small, reusable chunks of instructional media" in a way that teachers could "reassemble these parts in ways that support their individual instructional goals". In this sense, the LOM (2000) classic definition for Learning Objects is "any entity, digital or non-digital, which can be used, reused or referenced during technology supported learning". Briefly, it is common sense to refer them as reusable pieces of knowledge.

Time and accumulated experience has shown, however, that the reuse process for learning objects was not so straightforward as thought by the founders of this movement - Hodgins (2000), for instance, assertively has pointed out their potential for reusability, generativity, adaptability, and scalability. Many authors, like C. A. Allen \& Mugiza (2010) and the same Wiley, revisited (2014) discuss that many reusability problems of learning objects come, in fact, from their own definition, which is broad and nebulous in many ways, allowing the adoption of different - and incompatible - models for their design, development, and deployment, which in practice does not favor reuse in any way. Ochoa and Duval (2008) show that the reuse of Learning Objects with different granularities was around $20 \%$, which could be an indicative that the problem could really be on 
the essence of the design process of Learning Objects, more than in their individual granularities, as shown in Silveira et al. (2007).

The OER movement comes mainly to override the Learning Object concept, given the limitations that were perceived along the years. The Free Software definition is a keystone for it - under such definition, software users have the freedom to run, copy, distribute, study, change and improve the software. Namely, a computer program is considered free software if, and only if, it gives users adequately all of these four essential freedoms (Free Software Foundation [FSF], 2015):

- Freedom 0: The freedom to run the program as you wish, for any purpose.

- Freedom 1. The freedom to study how the program works, and change it so it does your computing as you wish.

- Freedom 2: The freedom to redistribute copies so you can help your neighbor.

- Freedom 3: The freedom to distribute copies of your modified versions to others.

It is important to remark that access to the source code is a precondition for Freedoms \#1 and \#3.

Abtar, Dunning, Harvinder, and Halimatolhanin (2004) suggest that the real degree of reuse of "traditional" Learning Objects refers only to Freedom \#0 of the Free Software Principle (freedom to run), i.e., Learning Objects are often retrieved from the repositories (or just found after a simple Web search) and used as they are - with no modification. The lack of modifications are justified by a wide range of factors, which vary from the simple inability of the user to perform any change in the object, to the lack of access to the Learning Object's source code. Even in the (rare) cases were source code is available to skilled users, of the object, open licenses are not mandatory for Learning Objects - many of them are available with restrictive licenses or even copyrighted.

On the other hand, open licenses are an essential part of OER definition. Like the Free Software principles, OER have well-accepted five rights, known as the 5R principles (Wiley, 2014):

- Retain - the right to make, own, and control copies of the content

- Reuse - the right to use the content in a wide range of ways

- Revise - the right to adapt, adjust, modify, or alter the content itself

- Remix - the right to combine the original or revised content with other open content to create something new

- Redistribute - the right to share copies of the original content, your revisions, or your remixes with others

The possibility to modify, reuse, remix and redistribute resources are the core principles of OER original proposal. The " 5 th $\mathrm{R}$ " refers to the ability to retain the license of the content. In this context, open licenses emerge as a way to allow all these actions while protecting authors' moral rights and providing a set of standards for copying and sharing content under a legal settlement, which is much more flexible than copyright. Thus, new open licenses, such as Copyleft or CC (Creative Commons), allow reuse and adaptation of digital resources, or their parts, according to different degrees of openness and distribution. Considering the range of possible CC licenses, among the most widely open license (CC BY - Attribution) and less open (CC BY NC ND - Attribution, Non-Commercial, No-derived) there is a wide spectrum of other possible licenses.

A broader vision of OER is found in initial documents such as the foundational Cape Town declaration or the more recent and complete UNESCO's Paris OER Declaration in 2012. A more pragmatic and strategic view of OER can be found in N. Allen, Browne, Forward, Green, and Tarkowski $(2015$, p. 2). This document points out that that OER must be both free (meaning "no 
cost") for anyone to access and to legally modify, according to the $5 \mathrm{R}$ principles above mentioned (Wiley, 2014). The same work states that typical strategic goals of OER are:

- Reducing barriers to education, including access, cost, language and format.

- Enabling the free access to and reuse of expressions of human knowledge, in all of its forms.

- Ensuring educators have the legal rights to retain, reuse, revise, remix and redistribute educational resources as they determine - without having to ask permission.

- Increasing the efficiency and effectiveness of public funds spent on education.

- Transforming teaching and learning by enabling effective, open pedagogy.

- Connecting communities of educators and learners around open content.

- Expanding the use of internet and digital technologies in education.

- Enhancing educational opportunities to foster development and more productive, free societies.

- Empowering educators to have more agency in the classroom.

It could be noted that many of the potentials of OER are also applicable to open courses, and OER that fully comply with the openness fundamentals could be the basis of open courses that could also rely on the same principles. This could increase the reach, impact, and possibly the effectiveness of open courses in situations of face-to-face or distance teaching and learning.

\section{The Road for Openness}

Many of the features commonly used in courses that purport openness (including MOOCs) are not OER, like videos and closed, non-editable or changeable instructional materials. This brings a dichotomy in relation to the concept of openness: MOOCs are open only in relation to access, but not in relation to their adaptability. Thus, it can be said that almost all the MOOCs offered by portals (commercial or otherwise) nowadays consist of courses that offer a set of materials that are not designed or developed under the aegis of the OER movement. This makes current MOOCs to ultimately be "closed" courses in fact under a technical point of view, since they are non-modifiable, non-remixable, non-shareable and so on. This preoccupation appears in a significant number of recent publications, like Atenas (2015) and Yeager and Bliss (2015), for instance.

The lack of openness significantly reduces MOOC's potential for reuse and adaptability for applications in individualized learning situations. Hewa and Cheung (2014) also pointed out that the quality of MOOC-based education and MOOC business models are other unresolved issues both related to the inherently closed nature of them. Besides, they could have an enormous potential for supporting adaptive and personalized learning if, and only if, they followed the openness principles, since there are a wide range of variables involving the individualization of educational processes such as individual learning styles, languages or conceptual prerequisites. Hood, Littlejohn, and Milligan (2015) consider the investigation of each singular learner particularly important, considering the particular ways to produce and share knowledge, as cited by Veletsianos, Collier, and Schneider (2015). In this sense, self-regulated learning in MOOCs in also a key feature to be addressed, which could be empowered under an open philosophy.

Alrami, Zo, and Ciganek (2014) emphasize the role of openness in MOOCs, together with university's reputation, as a crucial factor for which is called "MOOC continuance", which means some individual intention to continue or not using MOOCs after having experienced one or some of them.

Linked open data appears to be one of possible solutions for the dichotomy MOOC/OER, as shown by Piedra, Chicaiza, López, and Tovar (2015): by giving semantic interoperability among multiple OER repositories, it would be easier to describe, discover, link, publish and reuse them 
in MOOCs' instructional design. The usage of a Linked open data-based approach could help to solve the wide variety of standards, if any, used by OER repositories.

Following the openness principles, a MOOC could be regarded as a big, complex, coarse-granular OER. Under this view, Figure 1 shows some common practices in Open Education (at the left side) together with some features of open content:

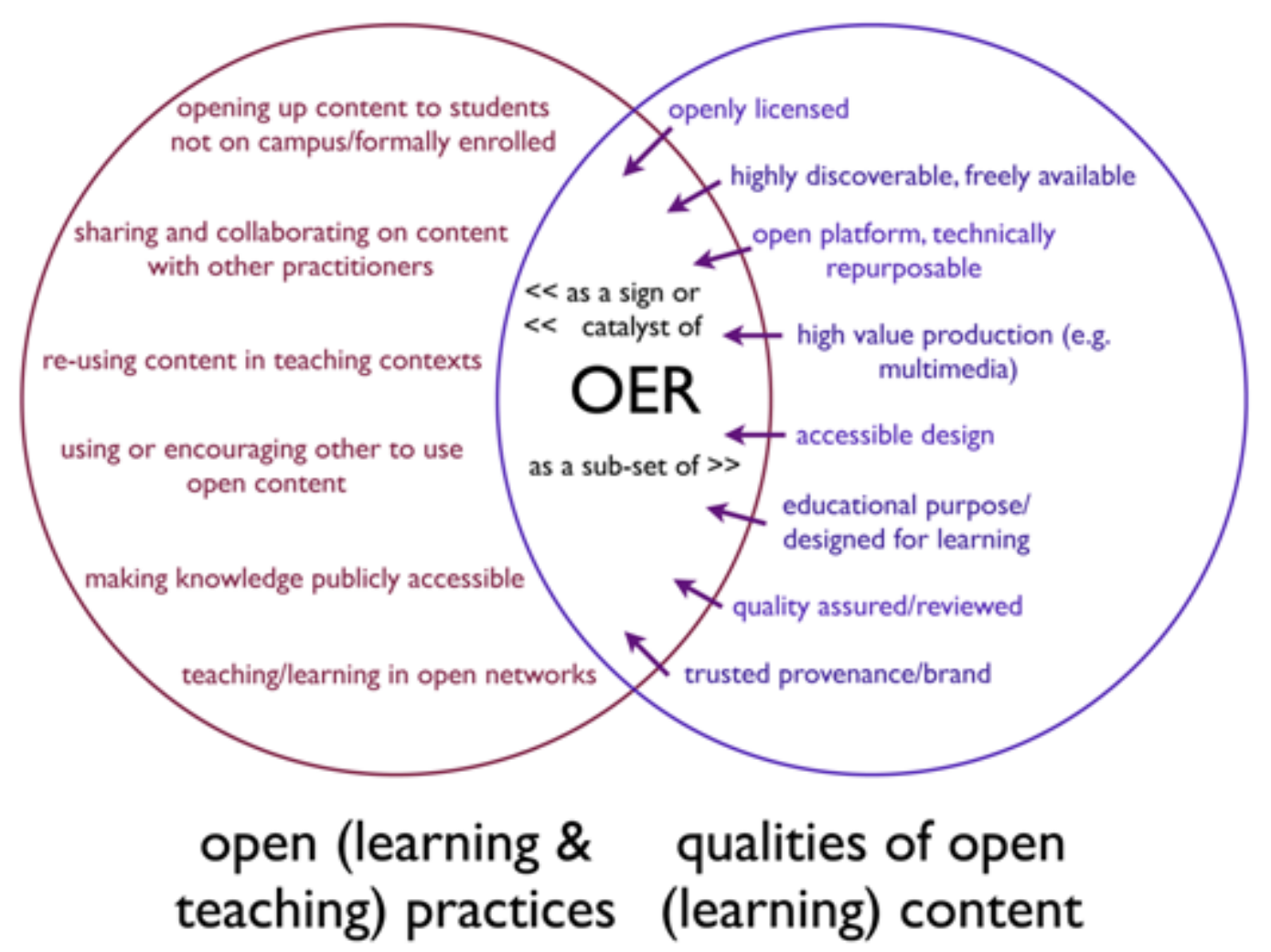

Figure 1: Open practices meets open content.

Source: N. Allen et al. (2015), licensed under CC.

All the aspects shown in Figure 1 are essential to the real opening of OER and MOOCs. In this sense, Castillo, Lee, Zahra, and Wagner (2015), Chew (2015) and N. Allen et al. (2015) present the main challenges of OER and MOOCs nowadays. The application of some principles of openness could give some hints about how to face these challenges, as shown in Table 1: 
Table 1: OER and MOOC current challenges

\begin{tabular}{|c|c|c|}
\hline Challenge & Context \& Facts & Roads to solution \\
\hline $\begin{array}{l}\text { Insufficient Aware- } \\
\text { ness }\end{array}$ & $\begin{array}{l}\text { - Few educational agents } \\
\text { (teachers and students) are } \\
\text { aware of OER and MOOCs } \\
\text { - The lack of awareness goes } \\
\text { beyond the discovery of their } \\
\text { existence: they have to be } \\
\text { considered as true alterna- } \\
\text { tives to currently used mate- } \\
\text { rials }\end{array}$ & $\begin{array}{l}\text { - A deeper understanding of } \\
\text { the benefits and potential in- } \\
\text { novations must be built } \\
\text { - If OER and MOOCs are } \\
\text { open enough to be adapted to } \\
\text { individual needs, their } \\
\text { awareness could naturally in- } \\
\text { crease } \\
\text { - MOOCs and OER awareness } \\
\text { could be significantly im- } \\
\text { proved if taken as part of } \\
\text { blended learning. This could } \\
\text { be achieved with more flexi- } \\
\text { bility for changes, provided } \\
\text { by openness. }\end{array}$ \\
\hline $\begin{array}{l}\text { Difficulty of Discov- } \\
\text { ery, Use and Remix }\end{array}$ & $\begin{array}{l}\text { - The discovery and reuse of } \\
\text { OER are not simple } \\
\text { - MOOCs' scenario is worst } \\
\text { regarding to reuse and remix, } \\
\text { but is relatively better related } \\
\text { to discovery - but not of their } \\
\text { individual parts } \\
\text { - Despite the existence of } \\
\text { plenty standards, OER re- } \\
\text { positories still presents com- } \\
\text { patibility problems. } \\
\text { - MOOCs' materials are } \\
\text { commonly copyrighted } \\
\text { - OER and MOOCs exist in a } \\
\text { huge variety of technical } \\
\text { formats } \\
\text { - Lack of specific open tools } \\
\text { for change and remix OER } \\
\text { and MOOCs. }\end{array}$ & $\begin{array}{l}\text { - Open licenses should be ap- } \\
\text { plied to MOOCs themselves } \\
\text { and theirs material, in order } \\
\text { to make them suitable for } \\
\text { remixing, sharing and modi- } \\
\text { fications. } \\
\text { - Open standards must be ap- } \\
\text { plied for repositories, as well } \\
\text { as open (and linked) data and } \\
\text { open technical formats have } \\
\text { to be refined } \\
\text { - Open media editing and re- } \\
\text { mixing tools must be devel- } \\
\text { oped and/or improved to } \\
\text { meet these new requirements }\end{array}$ \\
\hline
\end{tabular}


Table 1, continued: OER and MOOC current challenges

\begin{tabular}{|c|c|c|}
\hline Challenge & Context \& Facts & Roads to solution \\
\hline $\begin{array}{l}\text { Inconsistent Breadth } \\
\text { and Depth }\end{array}$ & $\begin{array}{l}\text { - The reach and distribution of } \\
\text { available OER and MOOCs } \\
\text { is uneven across knowledge } \\
\text { areas (this was a problem al- } \\
\text { ready with Learning Objects) } \\
\text { - It is frustrating if there is no } \\
\text { OER nor MOOC to be } \\
\text { adopted when people are } \\
\text { willing to } \\
\text { - MOOC major for-profit pro- } \\
\text { viders (like Coursera, Udaci- } \\
\text { ty and so) have limitations to } \\
\text { produce content for specific } \\
\text { publics, while local authors, } \\
\text { which could design relevant } \\
\text { online open courses, have } \\
\text { limitations to deliver them in } \\
\text { a proper way. }\end{array}$ & $\begin{array}{l}\text {-Widely changeable and } \\
\text { shareable OER and MOOCs } \\
\text { could dramatically increase } \\
\text { their availability } \\
\text { - The easiness for share, li- } \\
\text { cense, remix and edit OER } \\
\text { and MOOCs could encour- } \\
\text { age content producers (of all } \\
\text { types) to create new materi- } \\
\text { als. Open platforms (like } \\
\text { edX) would empower local } \\
\text { course builders to develop } \\
\text { and deliver their courses. }\end{array}$ \\
\hline Lack of Evidence & $\begin{array}{l}\text { - There are few studies that } \\
\text { shows evidence for the im- } \\
\text { pact of OER and MOOCs } \\
\text { - The aggressive business } \\
\text { models of many MOOC } \\
\text { players makes their effec- } \\
\text { tiveness to be criticized re- } \\
\text { garding traditional education } \\
\text { models }\end{array}$ & $\begin{array}{l}\text { - More case studies must be } \\
\text { developed to verify the ex- } \\
\text { pectancies. It depends on two } \\
\text { of the factors before men- } \\
\text { tioned: awareness and avail- } \\
\text { ability, besides of openness. } \\
\text { - MOOCs' business models } \\
\text { must be compatible to the } \\
\text { impact and effectiveness they } \\
\text { provide. New business mod- } \\
\text { els should be developed un- } \\
\text { der a scenario with full } \\
\text { openness. }\end{array}$ \\
\hline $\begin{array}{l}\text { Minimal Evidence of } \\
\text { Reuse }\end{array}$ & $\begin{array}{l}\text { - Reuse has been the key fac- } \\
\text { tor for OER; however, there } \\
\text { are not enough evidence of it } \\
\text { - Reuse in quite impossible in } \\
\text { many of current MOOCs be- } \\
\text { cause of copyright or tech- } \\
\text { nical limitations }\end{array}$ & $\begin{array}{l}\text { - More than open licenses, } \\
\text { OER and MOOCs must rely } \\
\text { on open formats and data in } \\
\text { order to increase their reusa- } \\
\text { bility }\end{array}$ \\
\hline
\end{tabular}


Table 1, still continued: OER and MOOC current challenges

\begin{tabular}{|c|c|c|}
\hline Challenge & Context \& Facts & Roads to solution \\
\hline $\begin{array}{l}\text { Reliance on Text- } \\
\text { books }\end{array}$ & $\begin{array}{l}\text { - Traditional courses are fo- } \\
\text { cused on textbooks as prima- } \\
\text { ry educational resource, } \\
\text { leaving OER to a second } \\
\text { place } \\
\text { - It is hard to find a single } \\
\text { textbook that meets all of } \\
\text { one's educational needs - } \\
\text { courses often use more than } \\
\text { one textbook. } \\
\text { - The cost of textbooks makes } \\
\text { them unaffordable for a con- } \\
\text { siderable amount of students } \\
\text { - Many textbooks are not } \\
\text { available online, even under } \\
\text { payment - which makes their } \\
\text { use impracticable for online } \\
\text { education }\end{array}$ & $\begin{array}{l}\text {-Textbooks could be built as } \\
\text { OER, empowering teachers } \\
\text { to collaboratively built their } \\
\text { own textbooks as OER } \\
\text { mashups (Silveira et al., } \\
\text { 2013). } \\
\text { Open textbooks initiatives, } \\
\text { like OpenStax - formerly } \\
\text { Connexions (Baker et al., } \\
\text { 2009) and LATIn - Latin } \\
\text { America open Textbook Ini- } \\
\text { tiative (Ochôa et al., 2011) } \\
\text { should be motivated. }\end{array}$ \\
\hline Sustainability & $\begin{array}{l}\text { - Current MOOCs, besides be- } \\
\text { ing offered mainly by profit- } \\
\text { able enterprises, suffer from } \\
\text { high dropout rates, which is } \\
\text { a threat to their sustainability } \\
\text { - OER are mainly supported } \\
\text { by public and philanthropic } \\
\text { funds, which can affect their } \\
\text { long-term sustainability }\end{array}$ & $\begin{array}{l}\text { - Part of MOOCs' current } \\
\text { dropout rates relies on the } \\
\text { non-adaptation of students to } \\
\text { the course proposals or mate- } \\
\text { rials. Openness features ap- } \\
\text { plied to MOOCs could make } \\
\text { them more suitable for dif- } \\
\text { ferent student profiles, since } \\
\text { they could be adapted. } \\
\text { MOOCs could become sets } \\
\text { of smaller, individualized } \\
\text { courses for specific audienc- } \\
\text { es } \\
\text { - OER initiatives could be } \\
\text { more auto-sustainable if } \\
\text { proper tools and resources } \\
\text { were free available, since the } \\
\text { production process would be } \\
\text { made easier and more feasi- } \\
\text { ble for a wider range of edu- } \\
\text { cational agents. }\end{array}$ \\
\hline
\end{tabular}


Table 1, finished: OER and MOOC current challenges

\begin{tabular}{|c|c|c|}
\hline Challenge & Context \& Facts & Roads to solution \\
\hline Expanding Inclusion & $\begin{array}{l}\text {-MOOCs' main premise was } \\
\text { to address issues of access } \\
\text { and equity, thus democratiz- } \\
\text { ing education across differ- } \\
\text { ences by culture, gender, } \\
\text { economic classes and ethnic- } \\
\text { ity. However, many barriers } \\
\text { (technical, cultural, linguis- } \\
\text { tic, etc.) prevent people to } \\
\text { gain access to them. New } \\
\text { for-profit business models } \\
\text { for MOOCs could erase this } \\
\text { premise. } \\
\text { - OER could help in digital in- } \\
\text { clusion of people, while } \\
\text { providing rich digital-based } \\
\text { content for educational pur- } \\
\text { poses; however, the lack of } \\
\text { awareness and other access } \\
\text { issues, similar to those faced } \\
\text { by MOOCs, prevent people } \\
\text { to have contact with them. }\end{array}$ & $\begin{array}{l}\text { - Openness, more than free ac- } \\
\text { cess, could bring the ability } \\
\text { of adapt some OER or } \\
\text { MOOC to local necessities, } \\
\text { like downsizing huge content } \\
\text { for poorer Internet connec- } \\
\text { tions or making cultural and } \\
\text { linguistic adaptations, for in- } \\
\text { stance } \\
\text { - There are some barriers, } \\
\text { however, which are not } \\
\text { breakable only by openness: } \\
\text { efforts came from other } \\
\text { fronts must be taken. }\end{array}$ \\
\hline Infrastructure & $\begin{array}{l}\text { Perhaps the most tangible } \\
\text { challenge for providing ac- } \\
\text { cess to MOOCs and OER } \\
\text { - The lack of sufficient tech- } \\
\text { nical infrastructure is a reali- } \\
\text { ty in many countries, espe- } \\
\text { cially those in under- } \\
\text { developed areas of the globe. }\end{array}$ & $\begin{array}{l}\text { - Public policies must be de- } \\
\text { veloped in order to improve } \\
\text { the Internet access to popula- } \\
\text { tion, as well as access to } \\
\text { proper devices. Open licens- } \\
\text { es for hardware, software and } \\
\text { content could make the pro- } \\
\text { cess affordable. } \\
\text { - The pervasiveness of mobile } \\
\text { devices, especially in devel- } \\
\text { oping countries, is a factor } \\
\text { that must be taken into ac- } \\
\text { count to develop MOOCs } \\
\text { and OER that are more mo- } \\
\text { bile-friendly. This task is } \\
\text { made easier if openness prin- } \\
\text { ciples are followed, since } \\
\text { courses and resources' inter- } \\
\text { faces could be changed to } \\
\text { become responsive. }\end{array}$ \\
\hline
\end{tabular}

Inspired by Figure 1, which pointed out the open education principles that should be embraced by OERs, together with their foundations that could be embedded by MOOCs, Table 1 presented a 
systematization of the challenges that OER and MOOC currently face to embrace the openness principles giving some directions to be considered in present and future research and development. This is the point which will be discussed in next section.

\section{Openness in MOOCs and OER: Present and Future}

Effectively, mixing OERs and MOOCs foundations under the openness core principles would force us to regard future openness-based MOOCs as aggregates of openness-based OERSs, and these ones as mutable, remixable pieces of one or many openness-based MOOCs. Part of this scenario, however, depends on the completion of some challenges presented in Table 1, while some aspects of it are more straightforwardly reachable.

Figure 2 schematizes these aspects, which will be commented afterwards.

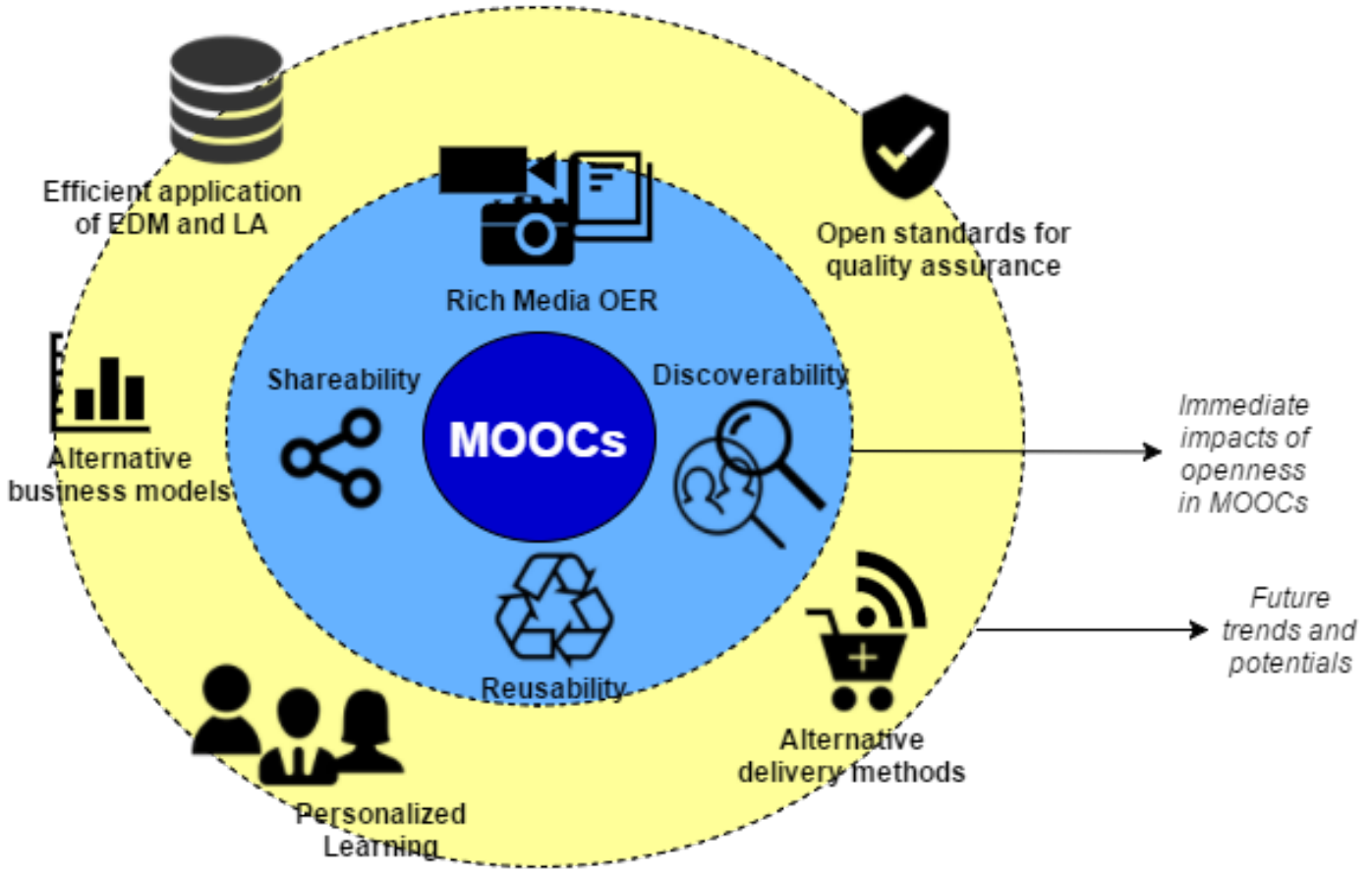

Figure 2: Immediate effects and future trends of applying open principles to MOOCs

In Figure 2, some immediate impacts of openness in MOOCs and OER include:

- Rich media OERs: MOOCs could have their components improved by embedding OER from many other sources. Open textbooks could be used to compose some syllabus' bibliography, as well as any sort of open content, from videos to games.

- Discoverability: MOOCs designed under such a perspective would have their contents easily reached by most search engines, which would increase their relevance in searches, nowadays limited by their "public" parts (title, authors, course description and any other sort of available metadata). More than this, networks of social agents related to the courses could also be disclosed, empowering these networks themselves or allowing new networks to be formed.

- Reusability: By allowing the access to more granular pieces - the OERs that are packed together to compose them, MOOCs that fulfill the openness requirements would increase their potential for being reused and reusing other MOOC's features. Since the context would not be lost (since every OER being used in this situation would be a part of some MOOC), the premises for properly reusing their pieces would not suffer from the prob- 
lem of de-contextualization, which was a commonplace when reusing OER (or old LOs) separately.

- Shareability: Regarding the new possibilities that would be open for modification and remix, MOOCs' potential for be shared - entirely or some of their parts - would naturally increase.

Besides, the movement of openness applied to MOOCs and OER brings a considerable amount of future opportunities in this new scenario, such as:

- Personalized Learning: Fully open MOOCs could be customized by professors or some faculty staff (or the students themselves) to fulfill the learning requirements of a specific group of students, or even just one; nowadays, this feature is commonly reached by offering the content, or part of it, as a SPOC (Small Private Online Course). More than this, an openness-based MOOC intelligent platform could grasp a wide variety of students' information and deliver a whole personalized course that meet particular learner's requirements (see EDM and LA topic below). Jarret (2013) brings an introductory overview about this subject, but with no emphasis to MOOC or OER.

- Alternative delivery methods: Every educational model has its delivery method, or a set of them. By "delivery method" it is understood the completion of mechanisms that are applied for providers to make their products reach their public, or the opposite, which clearly includes some business model. For MOOC providers, it includes the wide set of elements planned to attract, enroll and keep students engaged in their courses. Current xMOOCs share, with some slight differences, the same basic delivery methods, as well as "traditional", tutor-based online education providers did and still do. Such a new panorama for MOOCs and OER under the openness principles, together which a whole new generation of potential students which have grown in an interconnected - and potentially convergent - world, would make providers rethink their delivery methods (and their business models, as seen in the next topic). Hill (2012) traced some introductory discussions about online education delivery methods, with emphasis to MOOCs.

- Alternative business models: Costs of producing MOOCs and OER under the current models - with no or few concern about openness aspects - tend to be high, involving whole teams of professionals which spend their time and effort. The nature of these costs, as well the financial framework of MOOC and OER providers are deterministic factors about the business model to be adopted to deliver them. On the other hand, providers' financial frameworks depend clearly on how these organizations were funded and are sustained. New mechanisms of designing and producing OER and MOOCs will undoubtedly lead to new business models, which could complement or substitute the current ones. Pomerol, Epelboin and Thoury (2015) present ample discussion about business models for MOOCs, whilst Daniel, Cano and Cervera (2015) present an interesting counterpoint among Personalized Learning and the nowadays MOOCs business models. They cite the ongoing movement from a "freemium" model to a "premium" one, going against one of the main premises of the model.

- Efficient application of EDM and LA: Nowadays, major MOOC vendors effectively use Educational Data Mining (EDM) and sometimes Learning Analytics (LA) techniques mostly to forecast - and try to avoid - student dropout, whose rates are enormous in MOOCs. However, many of the times, all information available to them is limited to the data that could be caught inside some vendor platform, together with some other data available. The real opening of these MOOCs would bring a whole new reality for these techniques, allowing their implementations to have access to some pieces of information that are not available in the actual scenario. Papamitsiou and Economides (2014) present a very comprehensive review about EDM and LA 
- Open standards for quality assurance: Quality assurance for OER and MOOC currently relies mainly on providers' reputation, though some institutions have developed their own internal quality models for MOOCs. Hayes (2015) presents a brief review of recent literature on MOOC quality assurance. On the other hand, the scenario for OER quality assurance presents a greater maturity, clearly inherited from previous research on LO quality models. In this sense, the work of Camilleri, Ehlers, and Pawlowski (2014) presents an ample report on this subject, taking into account the main Open Education principles, which points to some probable directions for quality assurance in a scenario where openness would be the main guiding principle for MOOCs and OERs. In this case, open standards and frameworks for MOOC and OER quality assurance would assist in measuring quality in more globally accepted terms.

Certainly, to realize these aspects depicted by Figure 2, the challenges proposed in Table 1 must be faced by academia and industry, for the sake of the survival of MOOCs and OER initiatives. Both must evolve in order to fulfill the requirements of a growing educational scenario, and they must assume their original premise of being instruments for democratizing the access to education, from formal scholar situations to the most informal or vulnerable contexts.

\section{Conclusions}

MOOCs and OER still have a long way to reach all the openness requisites, with many challenges in common that must be faced in order to guarantee their own existence. Lack of awareness, limited reach, low reuse and incompatibility issues were problems already suffered by Learning Objects; all that research that developed repositories, federations and standards would prevent OER and MOOCs to fail victim to the same issues. However, the openness scenario brings a set of new future possibilities for the Open Education scenario that are not currently realizable while these challenges are not confronted. Many of these issues, however, depend on the action of several actors to be solved, like infrastructure, sustainability, and inclusion - but the openness principles could help to make OER and MOOCs more adaptable to specific publics, limitations and requirements.

Further works point to open quality assurance models, MOOCs and OER evaluation and accreditation, which confirm another class of issues, faced mainly by MOOCs, which suffers from the lack of worldwide accreditation standards. The path many MOOC vendors are following (using accreditations as the key point for profit) could reinforce the division among those who can or cannot afford an accreditation - instead of democratizing education, this choice would make MOOCs more and more an elitist consumer good. It must be studied how openness principles and their features could contribute to specify open accreditation and open evaluation standards, in order that fully open MOOCs and OER could accomplish their original missions, without deviations.

\section{References}

Abtar, K., Dunning, J., Harvinder, K., \& Halimatolhanin, M. (2004). How reusable are learning object templates: A case study. 4th Pan Commonwealth Forum, Dunedin, New Zealand.

Allen, C. A., \& Mugis, E. K. (2010). Improving learning object reuse through OOD: A theory of learning objects. Journal of Object Technology, 9(6), 51-75. Retrieved December 13, 2015 from http://doi.org/10.5381/jot.2010.9.6.a3

Allen, N., Browne, D., Forward, M. L., Green, C., \& Tarkowski, A. (2015). Foundations for OER strategy development. Retrieved November 20, 2015 from http://www.oerstrategy.org/home/read-the-doc/

Alrami, K., Zo, H. \& Ciganek, A. P. (2015). Understanding the MOOCs continuance: The role of openness and reputation. Computers \& Education 80, 28-38. 
Atenas, J. (2015). Model for democratization of the contents hosted in MOOCs. Revista de Universidad $y$ Sociedad del Conocimiento, 12(1), 3-14. Retrieved March 12, 2016 from http://journals.uoc.edu/index.php/rusc/article/view/v12n1-atenas

Atkins, D. E., Brown, J. S., \& Hammond, A. L (2007). A review of the Open Educational Resources (OER) movement: Achievements, challenges, and new opportunities. Report to the William and Flora Hewlett Foundation. Retrieved November 28, 2015 from http://www.hewlett.org/uploads/files/ReviewoftheOERMovement.pdf

Baker, J., Thierstein, J., Fletcher, K., Kaur, M., \& Emmons. J. (2009). Open textbook proof-of-concept via connexions. The International Review of Research in Open and Distributed Learning, 10(5). Retrieved December 8, 2015 from

Camilleri, A. F., Ehlers, U. F., \& Pawlowski, J (2014). State of the art review of quality issues related to open educational resources (OER). European Commission Joint Research Center Scientific and Policy Reports. Retrieved March 9, 2016 from http://is.jrc.ec.europa.eu/pages/EAP/documents/201405JRC88304.pdf

Castillo, N. M., Lee, J., Zahra, F. T., \& Wagner, D. A. (2015). MOOCS for development: Trends, challenges, and opportunities. Information Technologies \& International Development, 11(2), 35-42

Chew, L. K. (2015). Instructional strategies and challenges in MOOCs. Advances in the Scholarship of Teaching and Learning, 2(1), 41-50.

Daniel, J., Cano, E. V., \& Cervera, M. G. (2015). The future of MOOCs: Adaptive learning or business model? RUSC. Universities and Knowledge Society Journal, 12(1), 64-73. doi: http://dx.doi.org/10.7238/rusc.v12i1.2475

Free Software Foudation (FSF). (2015). What is free software? - The free software definition. Retrieved November 28, 2015 from http://www.gnu.org/philosophy/free-sw.en.html

Hayes, S. (2005). MOOCs and quality: A review of the recent literature. Quality Assurance Agency for Higher Education (QAA), 1288. Retrieved March 9, 2016 from http://eprints.aston.ac.uk/26604/1/MOOCs and quality a review of the recent literature.pdf

Hewa, K., \& Cheung W. (2014). Students' and instructors' use of massive open online courses (MOOCs): Motivations and challenges. Educational Research Review, 12, 45-58. Retrieved March 9, 2016 from http://www.sciencedirect.com/science/article/pii/S1747938X14000128

Hill, P. (2012). Online educational delivery models: A descriptive view. EDUCAUSE Review, 47(6), 84-97. Retrieved March 12, 2016 from https://net.educause.edu/ir/library/pdf/ERM1263.pdf

Hodgins, W. (2000). Into the future. Retrieved December 12, 2015 from http://www.learnativity.com/download/MP7.PDF

Hood, N., Littlejohn, A., \& Milligan, C. (2015). Context counts: How learners' contexts influence learning in a MOOC. Computers \& Education, 91, 83-91.

Jarret, J. (2013). Bigfoot, Goldilocks, and Moonshots. A report from the frontiers of personalized learning. EDUCAUSE Review, 42(2), 30-34. Retrieved March 12, 2016 from http://er.educause.edu/ /media/files/article-downloads/erm1323.pdf

LOM. (2000). LOM working draft v4.1 Retrieved December 12, 2015 from http://ltsc.ieee.org/doc/wg12/LOMv4.1.htm

Ochôa, X., \& Duval, E. (2008). Measuring learning object reuse. Third European Conference on Technology Enhanced Learning, EC-TEL 2008, Maastricht, Netherlands, 322-325.

Ochôa, X., Sprock, A. S., \& Silveira, I. F. (2011). Collaborative open textbooks for Latin America - The LATIn project. Proceedings of the iSociety 2011. Retrieved November 23, 2015 from http://ariadne.cti.espol.edu.ec/xavier/papers/Ochoa-iSociety2011.pdf

Papamitsiou, Z., \& Economides, A. (2014). Learning analytics and educational data mining in practice: A systematic literature review of empirical evidence. Educational Technology \& Society, 17(4), 49-64. 
Piedra, N., Chicaiza, J., López, J., \& Tovar, E. (2015). Seeking open educational resources to compose massive open online courses in engineering education - An approach based on linked open data. Journal of Universal Computer Science, 21(5), 679-711. Retrieved February 3, 2016 from http://www.jucs.org/jucs_21_5/seeking_open_educational_resources

Pomerol, J. C., Epelboin, Y., \& Thoury, C. (2015). MOOCs: Design, use and business models. London, UK: John Wiley \& Sons.

Reigeluth, C. M., \& Nelson, L. M. (1997). A new paradigm of ISD? In R. C. Branch \& B. B. Minor (Eds.), Educational media and technology yearbook (Vol. 22, pp. 24-35). Englewood, CO: Libraries Unlimited.

Rodés, V., Mustaro, P. N., Silveira, I. F., Omar, N., \& Ochôa, X. (2014). Instructional design models to support collaborative open books for open education. Proceedings of Interaccion'2014, Tenerife, Spain, 2014, paper \#93. Retrieved March, 12, 2016 from http://dl.acm.org/citation.cfm?id=2662346\&CFID $=761853641 \&$ CFTOKEN $=55770594$

Russel, D. M., \& Klemer, S. (2013). Will massive online open courses (MOOCs) change education? CHI 2013 Extended Abstracts, April 27-May 2, 2013, Paris, France

Shuwer, R., van Genuchten, M. ,\& Hatton, L. (2015). On the impact of being open. IEEE Software, 32(5), 81-83.

Silveira, I. F., Araújo, C. F., Amaral, L. H., Alcântara de Oliveira, I. C., Schimiguel, J., Ledôn, M. F. P., \& Ferreira, M. A. G. V. (2007). Granularity and reusability of learning objects. In A. Koohang \& K. Harman (Eds.), Learning objects and instructional design (pp. 139-170). Santa Rosa, California: Informing Science Press.

Silveira, I. F., Ochôa, X., Cuadros-Vargas, A., Casas, A. P., Casali, A., Ortega, A... Bieliukas, Y.H.C. (2013). A digital ecosystem for the collaborative production of open textbooks: The LATIn methodology. Journal of Information Technology Education: Research, 12, 225-249. Retrieved December, 15 from http://www.jite.org/documents/Vol12/JITEv12ResearchP225-246SilveiraFT89.pdf

Vardi, M. Y. (2012). Will MOOCs destroy Academia? Communications of the ACM, 55(11), 5.

Veletsianos, G., Collier, A., \& Schneider, E. (2015). Digging deeper into learners experiences in MOOCs: participation in social networks outside of MOOCs, notetaking, and contexts surrounding content consumption. British Journal of Educational Technology, 46, 570-580.

Yeager, C., \& Bliss, C. A. (2013). cMOOCs and global learning: An authentic alternative. Journal of Asynchronous Learning Networks, 17(2), 133-147.

Yuan, L., \& Powell, S. (2013). MOOCs and open education: Implications for higher education. A white paper. Retrieved March, 9 from http://publications.cetis.ac.uk/2013/667

Wiley, D. A. (2000). Connecting learning objects to instructional design theory: A definition, a metaphor, and a taxonomy. In D. A. Wiley (Ed.), The instructional use of learning objects: Online version. Retrieved November 28, 2015 from http://reusability.org/read/chapters/wiley.doc

Wiley, D. A. (2014). The access compromise and the 5th R. Retrieved December 13, 2015 from http://opencontent.org/blog/archives/3221 


\section{Biography}

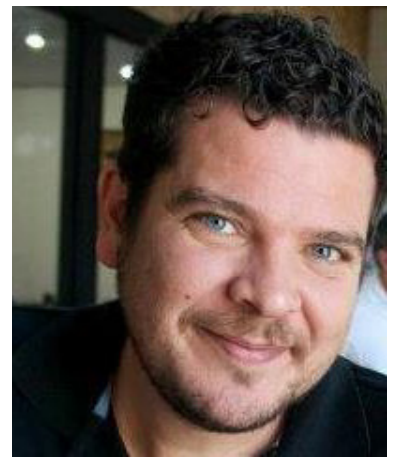

Ismar Frango Silveira received his $\mathrm{PhD}$ in Electrical Engineering at University of São Paulo (USP), his MSc. degree in Computer Sciences (CS) at Technological Institute of Aeronautics (ITA) and his BSc. In Mathematics at Federal University of Juiz de Fora (UFJF), all in Brazil. Nowadays, he is Professor at Mackenzie Presbyterian University and Cruzeiro do Sul University, both in São Paulo, Brazil, teaching in CS, Information Systems and Digital Games undergraduate courses and MSc. and PhD. programs on Math \& Sciences Teaching and Electrical Engineering/CS. 